UPPSALA UNIVERSITET
Working Paper 2008:16

Department of Economics

Hourly Wage Rate and Taxable Labor Income Responsiveness to Changes in Marginal Tax Rates

Sören Blomquist and Håkan Selin 
Department of Economics

Working paper 2008:16

Uppsala University

November 2008

P.O. Box 513

ISSN $1653-6975$

SE-751 20 Uppsala

Sweden

Fax: $+{ }_{4} 6184711478$

Hourly Wage Rate and Taxable Labor Income Responsiveness to Changes in Marginal Tax Rates

SÖREn BlomQuist and HÅkan Selin

Papers in the Working Paper Series are published on internet in PDF formats.

Download from http://www.nek.uu.se or from S-WoPEC http://swopec.hhs.se/uunewp/ 


\title{
Hourly Wage Rate and Taxable Labor Income Responsiveness to Changes in Marginal Tax Rates*
}

\author{
by \\ Sören Blomquist ${ }^{\mathrm{a}}$ \\ and \\ Håkan Selin ${ }^{b}$
}

\begin{abstract}
Recently, a voluminous literature estimating the taxable income elasticity has emerged as an important field in empirical public economics. However, to a large extent it is still unknown how the hourly wage rate, an important component of taxable income, reacts to changes in marginal tax rates. In this study we use a rich panel data set and a sequence of tax reforms that took place in Sweden during the 1980's to estimate the elasticity of the hourly wage rate with respect to the net-of-tax rate. While carefully accounting for the endogeneity of marginal tax rates as well as other factors that determine wage rates we do find a statistically significant response both among married men and married women. The hourly wage rate elasticity with respect to the net-of-tax rate is estimated to $0.14-0.16$ for males and 0.41-0.57 for females. In addition, we obtain uncompensated taxable labor income elasticities of around 0.21 for men and $0.96-1.44$ for women. In contrast to earlier studies, we also find significant income effects for males. Accordingly, for males the compensated taxable labor income elasticity is about 4 percentage points higher than the uncompensated one.
\end{abstract}

This version: November 19, 2008

Key words: Income taxation, hourly wage rates, work effort, taxable income JEL classification: H24; J22; J31

\footnotetext{
${ }^{*}$ We are grateful for comments from Dan Anderberg, Bertil Holmlund, Eva Mörk, Mårten Palme, Jukka Pirttilä, Arthur van Soest and seminar participants at the Federal Reserve Bank of Texas, Harvard/MIT, the IIPF conference in Warwick in 2007 and Uppsala University. Financial support from the Jan Wallander and Tom Hedelius Foundation is also gratefully acknowledged.

${ }^{a}$ Department of Economics, Uppsala University, P.O. Box 513, SE-751 20 Uppsala, Sweden, Email:

<soren.blomquist@nek.uu.se>

${ }^{\mathrm{b}}$ Department of Economics, Uppsala University, P.O. Box 513, SE-751 20 Uppsala, Sweden, Email:

$<$ hakan.selin@nek.uu.se>
} 


\section{Introduction}

Historically, the study of the behavioural response to changes in marginal tax rates has been centred on the labor supply choice. However, the standard labor supply model, where the individual chooses hours of work given an exogenous wage rate, abstracts from the possibility that the individual is able to affect her own wage rate. Indeed, it is not far-fetched to consider situations when a lower tax rate may induce the individual to change job, take on more difficult and compensated tasks, put in more effort into wage bargaining, alter form of compensation or simply work more intensely. Even though such changes in work effort and tax avoidance to a large extent are unobservable to the econometrician, behavioural changes along this margin are nevertheless likely to show up in altered hourly wage rates.

Reasoning along these lines has been one of the rationales of a growing body of research measuring the elasticity of taxable income with respect to the net-of-tax rate (one minus the marginal tax rate) with Lindsey (1987) and Feldstein (1995) as seminal contributions. However, it is still unknown if, or to what extent, individuals adjust their hourly wage rates in response to tax changes. Recent research on U.S. data (Gruber and Saez 2002, Kopczuk 2005 and Giertz 2007) indicates that much of the taxable income response lies in deduction behavior. $^{1}$

Here we address the issue of hourly wage rate responsiveness by employing a rich survey and register data set created from the 1981 and 1991 waves of the Swedish Level of Living Survey. ${ }^{2}$ In particular, we have access to a survey variable on the individual's hourly wage rate on a longitudinal basis. Between 1981 and 1991 top marginal tax rates were cut by 34 percentage points in Sweden in a piecemeal fashion. This sequence of tax reforms created substantial individual exogenous variation in marginal tax changes depending on tax bracket in 1981. In this paper we exploit this exogenous variation, together with the rich panel data material, to test whether hourly wage rates are sensitive or not to changes in marginal tax rates.

While carefully accounting for the endogeneity of marginal tax rates as well as other factors that determine wage rates we do find a statistically significant response both among married men and women: The estimates of the hourly wage rate elasticity with respect to the net-of-tax rate range from 0.14 to 0.16 for married males and from 0.41 to 0.57 for married

\footnotetext{
${ }^{1}$ See Giertz (2004) for a survey of the recent U.S. literature.

${ }^{2}$ See, for example, Fritzell and Lundberg (1994) for a description of this data source.
} 
females. Seen from the perspective that wage rates traditionally have been assumed to be exogenous in labor supply models these estimates must be thought of as surprisingly large.

In line with previous literature, we have also estimated the elasticity of taxable labor income with respect to the net-of-tax rate. For married men we obtain (uncompensated) taxable labor income elasticities of around 0.21. For women the corresponding estimates range from 0.96 to 1.44 . Taxable labor income is defined as the earnings net of costs of earning the income.

We improve upon existing studies in one additional crucial respect: we specify virtual incomes and set out to estimate non-labor income elasticities. For males we find a statistically significant non-labor income elasticity with expected sign: -0.07 . The corresponding estimates for females are not significantly different from zero. Armed with these elasticities we are able to compute compensated elasticities. For males, an uncompensated elasticity of 0.21 corresponds to a compensated taxable labor income elasticity of 0.25 . Interestingly, our finding of significant income effects conflicts with a frequently cited result in Gruber and Saez (2002). Using a different methodology, they did not find significant income effects on U.S. data from the 1980's.

Our paper also adds to a growing literature that examines tax responsiveness on Swedish data. From different methodological perspectives Gelber (2008), Hansson (2007), Holmlund and Söderström (2007), Ljunge and Ragan (2006) and Selén (2005) all exploit large register data sets and study how mostly earned income reacts to changes in net-of-tax rates. However, none of these papers utilizes the Swedish Level of Living Survey and none of these make a separate analysis for hourly wage rates.

The paper is structured as follows. In the next section we briefly describe the income tax changes that occurred between 1981 and 1991 in Sweden; a more thorough description is given in appendix A. In section 3 we discuss a number of methodological issues. These involve our treatment of income effects, our model framework and instrumentation procedure. Section 4 contains a description of the data source. The estimation results are presented and analyzed in section 5 . Section 6 concludes.

\section{Swedish income tax reforms 1981-1991}

In 1981 top marginal taxes were near a historical high; taxpayers in the highest bracket were subject to a marginal tax rate of 85 percent. As can be seen from Figure 1, which depicts the evolution of top marginal tax rates during the relevant time period, there was a steady decline in top marginal tax rates between 1981 and 1991. The most dramatic cut occurred in 
conjunction with the profound tax reform of 1991, sometimes called 'the tax reform of the century' (Agell et. al. 1998), when top marginal taxes fell by 15 percentage points. ${ }^{3}$ However, if one considers the whole period 1981-1991 marginal taxes were reduced by 34 percentage points for those who were in the top bracket in 1981.

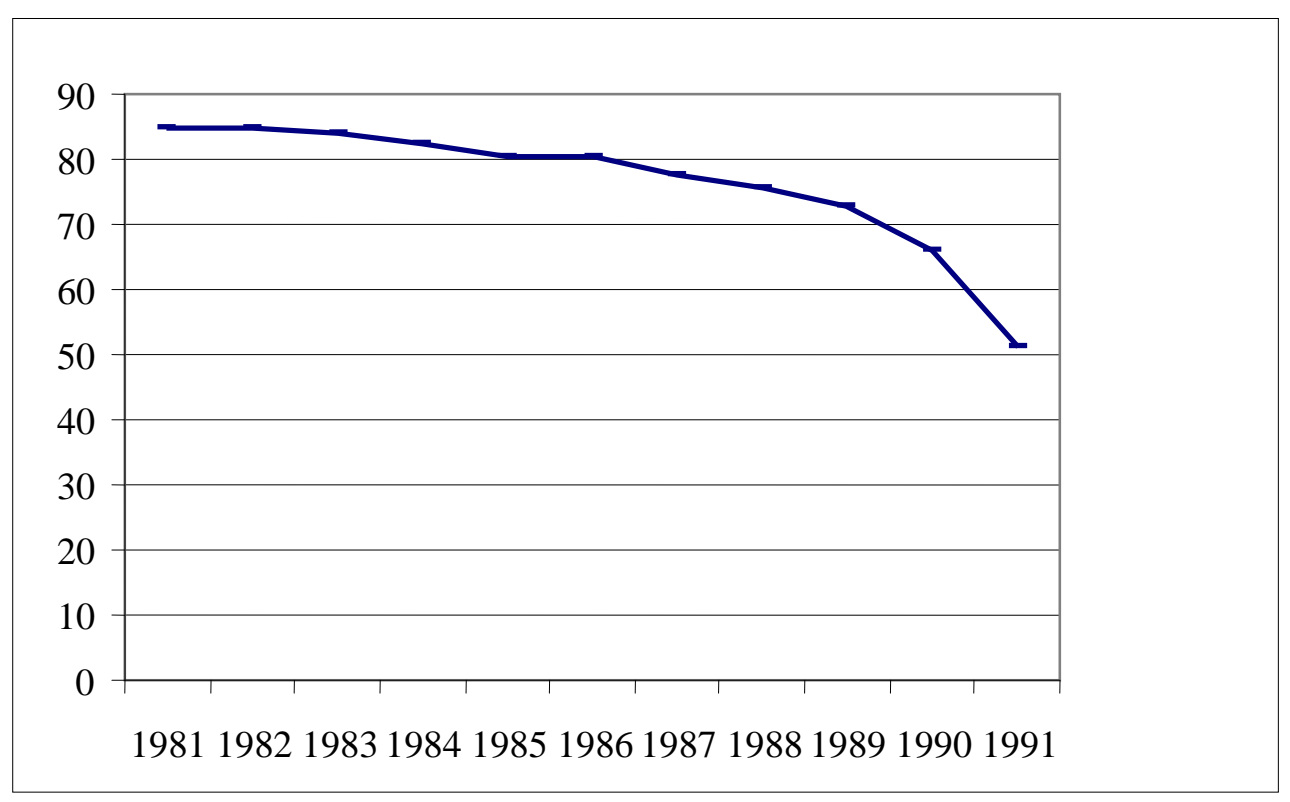

Figure 1. Top marginal tax rates 1981-1991 in percent by year.

Figure 2 illustrates average marginal tax rates for 1981 and 1991 by income decile in our estimation sample, where income deciles have been defined based on taxable labor income as of 1986. Marginal tax rates has been computed while taking both the statutory income tax schedule and means-dependent housing allowances into account. Apparently, income tax progressivity has been considerably reduced between the two years. The largest decrease in marginal tax rates was in the $10^{\text {th }}$ decile, whereas the tax changes were noticeably more modest in the two bottom deciles. Indeed, there were also considerable reductions in marginal tax rates in the middle of the income distribution. The main reason is that the 1981 statutory tax schedule was very progressive even at moderate income levels.

\footnotetext{
${ }^{3}$ The timing of the 1991 Swedish tax reform coincided with the most severe macroeconomic downturn since the 1930 's, and the recession has rendered appraisals of the reform more difficult. In June 1990, the unemployment rate was 1.1 percent, while it in the same month of 1993 was 9.0 percent (SCB 2005). Our interpretation is that the soaring unemployment rates pose a minor problem to our study that uses data from 1981 and 1991. First, on an annual basis the unemployment rate was 3.0 percent in 1991, which can be compared with 2.5 for 1981 . Second, the biggest increase in unemployment was among younger individuals. Since our sample contains individuals aged 22-54 in 1981 and 32-64 in 1991 our sample was affected to a less extent by the macroeconomic crisis.
} 


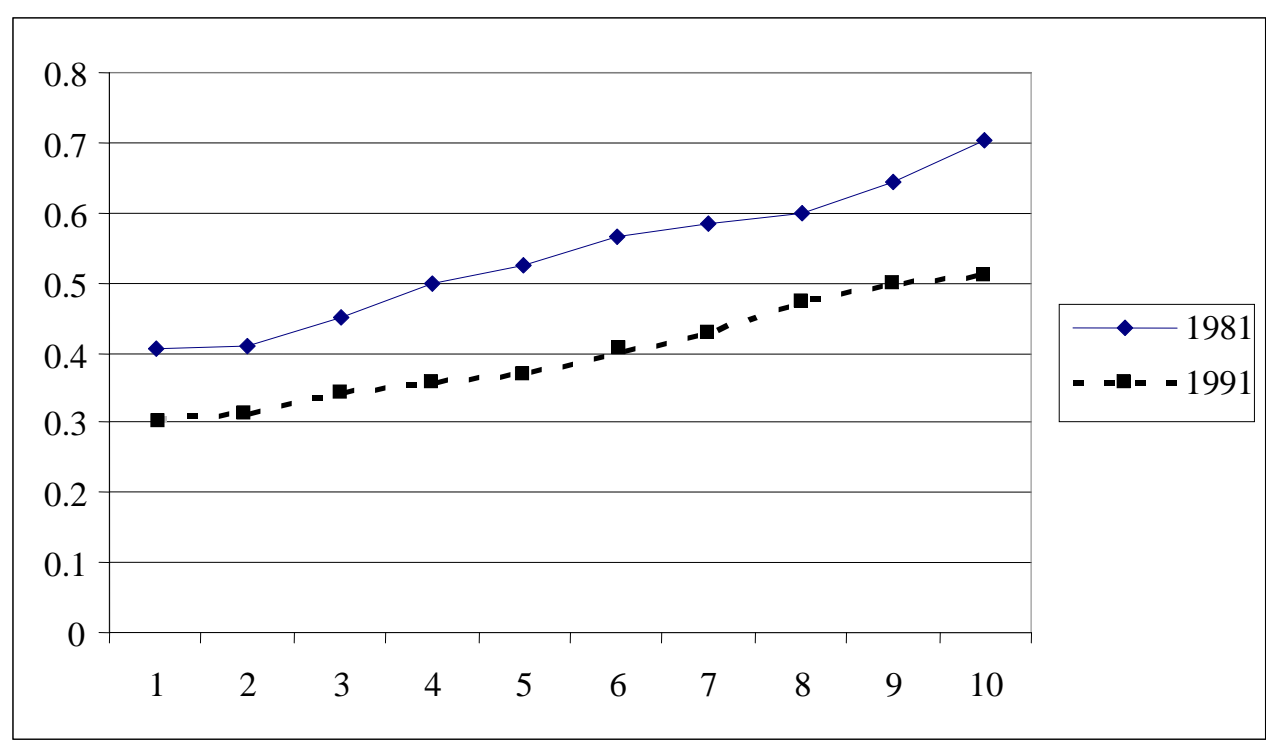

Figure 2. Average marginal tax rates in 1981and 1991 by deciles based on taxable labor income in 1986.

\section{Methodological considerations}

\subsection{Taxable income model}

In what follows, we briefly describe the canonical taxable income model as presented in Gruber and Saez (2002) to get a framework for interpreting the taxable income elasticities. The wage rate responses cannot be interpreted within that model. Therefore, in section 3.2 we also discuss a model where the individual can vary both work effort and hours worked.

Following Gruber and Saez (2002) we depart from a model of utility maximization where the individual chooses her optimal amounts of consumption, $C$, and taxable income $z$, subject to the budget constraint $C=(1-\tau) z+R$, where $\tau$ is the marginal tax rate on a linear segment of the income tax schedule and $R$ is virtual income. In a Swedish institutional context it is natural to interpret $z$ as taxable labor income. ${ }^{4}$ Optimization yields optimal taxable income supply functions of the form $z=z((1-\tau), R)$. The uncompensated taxable income elasticity with respect to the net-of-tax rate, $(1-\tau)$, can then be decomposed according to the Slutsky relationship

\footnotetext{
${ }^{4}$ In fact, this is also most appropriate from a theoretical point of view. The proposition that the taxable income elasticity captures all behavioural responses necessary to evaluate the deadweight loss of income taxation has been developed in static models where unearned income has been taken as given. See e.g. Chetty (2008).
} 


$$
\zeta^{u}=\zeta^{c}+\zeta_{R} \frac{(1-\tau) z}{R}
$$

where $\zeta^{c}$ is the compensated taxable income elasticity with respect to $(1-\tau)$ and $\zeta_{R}$ is the virtual income elasticity.

Despite the well-known fact that $\zeta^{c}$ is the central parameter needed for welfare evaluation (see e.g. Feldstein 1999), the previous literature has so far not set out to specify $R$ and to estimate $\zeta_{R}$. A large amount of works (Feldstein 1995, Auten and Carroll 1999 and others) implicitly assumes that $\zeta_{R}=0$. On the other hand, Gruber and Saez (2002) derives an empirical equation that includes an approximation of the term $[(d R-z d \tau) / z(1-\tau)]$ as a way to control for the income effect of a tax change. The approximations made by Gruber and Saez are, however, only valid for small tax changes and rather poor approximations of larger ones.

In this paper we specify virtual incomes by adopting a standard procedure in the labor supply literature. Let $\left(1-\tau_{i}\right)$ and $R_{i}$ be the net-of-tax rate and virtual income for an individual located on the $i$ :th segment of the tax schedule. The budget constraints have been calculated while taking the actual values of the parameters that determine the budget constraint as given. These parameters include unearned income (positive or negative), the number of children in the household and geographical location. ${ }^{5}$ Here we only consider individuals who are placed on locations where the income tax function is differentiable. ${ }^{6}$ In contrast to earlier taxable income studies on Swedish data (Holmlund and Söderström 2007, Ljunge and Ragan 2005, Selén 2004 and Hansson 2007) we have not only taken the statutory income tax schedule into account in the tax calculations, but also the marginal effects from means-tested housing allowances. Suppose that the budget constraint consists of $N$ segments and let $\bar{z}_{i}$ be the upper kink point in terms of of the $i$ :th segment. We then define virtual income of the first segment, $R_{1}$, as

\footnotetext{
${ }^{5}$ See appendix A for a detailed description of the tax and transfer system.

${ }^{6}$ In our estimation sample, 3 men and 2 women were located at kink points in 1981. Since the marginal tax rates are not defined for these, we have deleted these few observations in the empirical analysis.
} 
$R_{1}=$ capital income (net - of - tax) +

+ imputed income from owner occupied housing (net - of - tax) +

+ child allowance + housing allowance (at zero hours of work) +

+ disposable income of the spouse

Virtual incomes in upper segments, $i=(2, N)$, can be written as $R_{i}=R_{i-1}+\left[\left(1-\tau_{i-1}\right)-\left(1-\tau_{i}\right)\right] \bar{z}_{i-1}$ (c.f. Blomquist 1988). Since individuals differ with respect to their non-labor income $R_{1}$, individuals that are placed on the same segment of the income tax schedule will in general have different virtual incomes.

\subsection{Why do hourly wage rates change over time?}

There are at least three reasons why individual hourly wage rates vary over time: (i) because an individual's effort in a broad sense changes, (ii) because a larger or smaller part of the compensation is taken in the form of fringe benefits instead of regular cash pay or (iii) because of general equilibrium effects when either the supply or demand for labor shifts. These shifts in demand and supply curves might be caused by changes in the income tax system, pay roll taxes or other factors unrelated to taxes, such as changes in technology or shifts in the demand for goods. The focus of our study is not on the general equilibrium effects of the taxes, but on how a single individual reacts to changes in the net-of- tax rate and in the virtual income.

The first set of changes can be divided into at least four types of behavioural changes, more effort on present job, switching to a better paid job that requires more effort, a geographical move to a better paid job and investments in human capital. In the next section we lump together these four types of adaption to the tax system and study how an individual chooses effort defined in a very broad sense.

Part of the compensation for work comes in other forms than wages. In Sweden the most important such compensation would probably be occupational pensions. In the US company paid health insurance would be a major fringe benefit. How large part of total compensation that comes in the form of wages is probably influenced by tax laws as well as tax rates. Since these laws change over time the division of total payment between fringe benefits and wages will probably also vary over time. It also implies that the wage response to a change in the marginal tax can differ over time, if the rules governing how fringe benefits are taxed have changed. This is essentially the point made in Slemrod and Kopczuk (2002) 
when discussing the elasticity of taxable income. The parameters estimated in the taxable income literature are in general reduced form parameters where the parameters reflect both underlying preferences as well as other properties of the tax system than those described by the marginal tax rates. ${ }^{7}$

The third set of changes can be of several kinds. In an economy where the wage rate is market determined the change in taxes might lead to a shift in the aggregate supply seen as a function of the wage rate for a standard unit of work, and a movement along the demand curve with a decrease in the market wage if aggregate hours has increased and an increase if aggregate hours have decreased. If wages are largely determined by union contracts, the "market” wage might still be affected by the change in taxes. Changes in the payroll tax will like wise shift the demand curve and the equilibrium wage for a standard unit of work.

It can be of help for the empirical specification to formally model the influences on the wage rate listed above. The market responses to changes in the tax system might be different for different wage groups as they belong to different segments of the labor market. The same applies for exogenous productivity growth. Here we assume that the wage for an individual $i$ in group $j$ at time $t$ is given by

$W_{i j t}=\omega\left(E_{i j t}, \gamma_{i j t}\right) A_{j}\left(\right.$ taxsystem, technology $y_{t} e^{\varepsilon_{i j t}}$

where $E$ is effort level, $\gamma$ a vector of individual characteristics and $\varepsilon$ a random term. The function $A_{j}$ is meant to give the equilibrium wage rate for a standard unit of labor of type $j$. It depends on the intersection of demand and supply curves of labor seen as a function of the wage rate for a standard unit of labor. We assume this function varies between groups.

Taking logs and differencing between time $t$ and $t$-k we obtain:

$\ln \left(W_{i j t} / W_{i j t-k}\right)=\ln \left\lfloor\omega\left(E_{i j t}, \gamma_{i j t}\right) / \omega\left(E_{i j t}, \gamma_{i j t-k}\right)\right\rfloor+\ln \left(A_{j} / A_{j t-k}\right)+\left(\varepsilon_{i j t}-\varepsilon_{i j t-k}\right)$

In this paper we are interested in the parameters of $\ln \omega(E, \gamma)$. In the next section we give a model for the behaviour generating this wage function. One should keep in mind that since the wage rate is an important component of taxable income the above remarks are valid also for taxable income.

\footnotetext{
${ }^{7}$ See also Blomquist (1988) and Heim and Meyer (2004) for discussions of how parameters in behavioural relations sometimes is a mixture of preference parameters and parameters of the budget constraint.
} 


\subsection{Empirical model for hourly wage rates}

Consider a simple extension of the standard neo-classic static labor supply model, where the individual also has the option to choose the optimal amount of work effort. Let $E$ denote work effort (interpreted broadly so as to accommodate all the types of adaption listed under point (i). above). Individuals maximise utility according to the well-behaved utility function $U=U(C, E, H)$. We assume that $W=m \omega(E, \gamma)$, where $m$ from the individual's point of view is a constant. In what follows, we normalize $m$ to be one. Given that the individual is located on a linear segment of the income tax function the budget constraint can be expressed as $C=(1-\tau) \omega(E, \gamma) \times H+M$, where $\tau$ is the marginal tax rate, $C$ is consumption, $H$ is hours of work and $M$ is virtual income. After optimisation we obtain optimal hourly wage rate functions of the form $W=\omega\{E[(1-\tau), M, \gamma] ; \gamma\}$. In this paper we will impose the following functional form assumption for $\omega\{E[(1-\tau), M, \gamma] ; \gamma\}$ :

$\ln \omega_{i t}=\alpha_{1} t+\alpha_{2} \ln (1-\tau)_{i t}+\alpha_{3} \ln M_{i t}+\alpha_{4} t \gamma_{i}+\alpha_{5} \gamma_{i}$

where, again, $i$ indexes individuals and $t$ time. As seen above, a time effect is assumed to work linearly both independently and through the vector of individual characteristics $\gamma$, which are supposed to be time-invariant.

Before proceeding we make the observation that the virtual income term $M_{i t}$ is unobservable in the context of a model where the individual chooses both work effort and hours of work. However, for a given amount of effort the budget constraint is observable in the $(C, H)$-plane. Here, we will approximate $M_{i t}$ from the $(C, H)$-plane while treating the effort level as fixed. The computation of the virtual income term $M_{i t}$ for this model will therefore coincide with the computation of $R$ for the taxable income supply model described in section 2.1. Taking first differences of (5) between time $t$ and $t-k$ we obtain

$$
\ln \left(\omega_{i t} / \omega_{i t-k}\right)=\alpha_{1} k+\alpha_{2} \ln \left[(1-\tau)_{i t} /(1-\tau)_{i t-k}\right]+\alpha_{3} \ln \left(M_{i t} / M_{i t-k}\right)+\alpha_{4} k \gamma_{i}
$$

Combining (6) with the terms in equation (4) that are outside the control of the individual we obtain: 


$$
\begin{aligned}
& \ln \left(W_{i j t} / W_{i j t-k}\right)= \\
& \alpha_{1} k+\alpha_{2} \ln \left[(1-\tau)_{i j t} /(1-\tau)_{i j t-k}\right]+\alpha_{3} \ln \left(M_{i j t} / M_{i j t-k}\right)+\alpha_{4} k \gamma_{i j}+\ln \left(A_{j} / A_{j t-k}\right)+\left(\varepsilon_{i j t}-\varepsilon_{i j t-k}\right)
\end{aligned}
$$

The $\gamma_{i j}$-vector might contain both observed and unobserved characteristics. To account for observable characteristics that interact with the time trend we include quadratics in years of schooling, years of work experience, age and the number of children. In similarity with e.g. Auten and Carroll (1999), Sillamaa and Veall (2001), Aarbu and Thoresen (2001), Hansson (2007) and others, we let the set of individual characteristics be measured in the base period.

We also need to control for time-invariant individual unobserved factors (like innate ability) that interact with the time trend as well as aggregate factors. The former are captured by the $\ln \left(A_{j} / A_{j t-k}\right)$ term in (7). In principle, if we were able to find a good proxy variable for the unobserved heterogeneity at the individual level this would account for wage growth factors both at the individual level and at the group level.

Wooldridge (2002, p.63-67) suggests that the dependent variable from an earlier period can be used as a proxy for unobserved heterogeneity. Basically, we adopt this procedure here. Since we do not have access to lagged hourly wage rates for a sufficient number of observations in our sample we use the log of lagged taxable labor income as a proxy variable in the hourly wage rate regressions. To lessen the influence from transitory shocks in income, we use the log of a three year average of taxable labor income in 1975, 1976 and $1977 .{ }^{8}$ To avoid any correlation between $\left(\varepsilon_{i j t}-\varepsilon_{i j t-k}\right)$ and the proxy variable we utilize income variables from 4-6 years before the base year 1981 .

In addition, we allow for the possibility that the unobserved heterogeneity affects wage growth differently depending on which segment of the labor market the individual belongs to. We divide the entire sample (men and women pooled) into 10 groups and let the the $j$ :th group of the labor market be defined by the $j$ :th decile, where deciles are based on the income measure that is constructed from the 1975-77 income variables. Along these lines, to some of the regressions we add a 10-piece spline function in our logged averaged lagged income variable. The knots of the spline are defined by the deciles. ${ }^{9}$ As we use observations from 1981 and 1991 our estimating equation then becomes

\footnotetext{
${ }^{8}$ The variable is constructed in the following way: $\ln \overline{T L I}=\ln \left(\sum_{k=75}^{77} T L I_{k} / v\right)$ where $T L I$ is taxable labor income and $v$ is the number of years for which $T L I>0$.

${ }^{9}$ A 10 -piece spline in income has earlier been added to the right-hand side of regression equations in e.g. Gruber and Saez (2002) and Kopczuk (2005). Our motivation is somewhat different though.
} 


$$
\begin{aligned}
& \ln \left(W_{i j 1991} / W_{i j 1981}\right)=\gamma_{0}+\gamma_{1} \ln \left(\left(1-\tau_{i j 1991}\right) /\left(1-\tau_{i j 1981}\right)\right) \\
& +\gamma_{2} \ln \left(M_{i j 1991} / M_{i j 1981}\right)+\gamma_{3} X_{i j 1981}+f\left(\ln \overline{T L I}_{i j}\right)+\left(\varepsilon_{i j 1991}-\varepsilon_{i j 1981}\right)
\end{aligned}
$$

where $X_{i j 1981}$ is a vector of control variables and $f\left(\ln \overline{T L I}_{i j}\right)$ is a function of the $\log$ of average lagged taxable labor income. We will also run similar regressions with the change in the log of taxable labor income, $\ln \left(T L I_{i j 1991} / T L I_{i j 1981}\right)$, as the dependent variable. The log-log specification has earlier been used by a majority of authors in the taxable income literature, e.g. Auten and Carroll (1999), Gruber and Saez (2002) and Kopzcuk (2005).

\subsection{Endogenous regressors}

The most apparent methodological challenge involved in estimating (8) is that the location of the individual on the income tax schedule is a function of the dependent variable. Thus, movements in the contemporaneous error term do not only affect the wage rate or taxable labor income variable, but the net-of-tax rate and virtual income regressors as well. What are then needed are valid instruments for $\ln \left[\left(1-\tau_{i t}\right) /\left(1-\tau_{i t-k}\right)\right]$ and $\ln \left(M_{i t} / M_{i t-k}\right)$.

Previous literature analyzing taxable income responsiveness with panel data has almost exclusively, in some way or another, used instruments that are functions of first period income. It has become a common practice (Auten and Carroll 1999, Gruber and Saez , Kopczuk 2005 and others) to construct instruments by computing 'synthetic marginal tax rates' based on taxable income in the first period. ${ }^{10}$ Let $z_{i t}$ refer to taxable income, $\tau_{i t}$ to the marginal tax rate and $p$ to an index that is either a wage, income or a consumer price index. Then the standard instrument for $\ln \left\{\left[1-\tau_{i t}\left(z_{i t}\right)\right] /\left[1-\tau_{i t-k}\left(z_{i t-k}\right)\right]\right\}$ is $\ln \left\{\left[1-\tau_{i t}\left(p z_{i t-k}\right)\right] /\left[1-\tau_{i t-k}\left(z_{i t-k}\right)\right]\right\}$, where $\tau_{i t}\left(p z_{i t-k}\right)$ is the marginal tax rate as a function of the tax law of period $t$ and the taxable income in the base period, $z_{i t-k}$. It has been alleged that the change in the log of the synthetic marginal tax rates, $\ln \left\{\left[1-\tau_{i t}\left(p z_{i t-k}\right)\right] /\left[1-\tau_{i t-k}\left(z_{i t-k}\right)\right]\right\}$, only should reflect pure exogenous tax law changes and exclude behavioral ones.

\footnotetext{
${ }^{10}$ Other strategies to instrumenting that rely on first period income are e.g. Feldstein (1995) who groups taxpayers by their pre-reform marginal tax rates in difference-in-difference estimations, an approach that has been extended to a regression framework by Moffitt and Wilhelm (2000). The sole exception that we know of is Carroll (1998) who obtains a tax instrument by using an average of taxable income between the two years of investigation.
} 
However, as highlighted by Moffitt and Wilhelm (2000), it is in general unlikely that $Z_{i t-k}$ is correlated to the same degree with $\varepsilon_{i t}$ as with $\varepsilon_{i t-k}$. Consequently, $Z_{i t-k}$ is probably correlated with $\varepsilon_{i t}-\varepsilon_{i t-k}$. In the literature, this problem is frequently dealt with by including some function of $z_{i t-k}$ into the regression equation as a proxy for the transitory element in $\varepsilon_{i t-k}$ as well as trends in the income distribution. ${ }^{11}$ However, we have not seen any proof that this procedure actually solves the endogeneity problem.

In this study we propose a new kind of instrument for the change in the log net-of-tax rate that is not a function of base year income. Our instrument will be of the form $\ln \left\{\left[1-\tau_{i t}\left(\hat{z}_{i t}\right)\right] /\left[1-\tau_{i t-k}\left(\hat{z}_{i t-k}\right)\right]\right\}$ where $\hat{z}_{i t}$ denotes imputed taxable labor income for period $t$. As explained above, in our study we use a 10-year difference, more specifically we set $t=1991$ and $t-k=1981$. To obtain $\hat{z}_{i t}$ we have regressed both $z_{i 1991}$ and $z_{i 1981}$ on a fourth order polynomial in $Z_{i 1986}$, a set of controls for individual characteristics based on their 1981 values and a full set of interaction variables between $Z_{i 1986}$ and the socio-demographic control variables. ${ }^{12}$ The vector of individual characteristics is identical to the one included in the main regression equation and is based on the values of these variables as measured as of 1981 .

The key feature of our instrument is that it is a function of taxable labor income in 1986, i.e. the year in the middle of the year difference. The presumption is that $\varepsilon_{i 1986}$ is uncorrelated with $\varepsilon_{i 1991}-\varepsilon_{i 1981}$. The intuitive appeal of the instrument is that, even in the presence of substantial first-order auto-correlation in $\varepsilon_{i t}$, a transitory shock in $\varepsilon_{i 1981}\left(\varepsilon_{i 1986}\right)$ has a negligible impact on $\varepsilon_{i 1986}\left(\varepsilon_{i 1991}\right)$.

Since the virtual income also depends on the location at the income tax schedule $\ln \left(M_{i t} / M_{i t-k}\right)$ is instrumented in the same vein.

\section{Data}

The data come from the 1981 and 1991 waves of the Swedish Level of Living Survey, designed to be representative of the Swedish population. The questionnaires for these two years resemble each other to a high degree. We have also had access to register data on the

\footnotetext{
${ }^{11}$ Kopczuk (2005), who stacks many year-differences and construct instruments based on base year income constructs separate controls for the trend in the income distribution and the transitory component of the error term. He both controls for functions of log income for the year before the base year and the difference between base year income and the income for the year preceding the base year.

${ }^{12}$ Men and women have been pooled in these two auxiliary regressions. The adjusted $R^{2}$-values are around 0.96 in the separate regressions for $Z_{i 1981}$ and $Z_{i 1991}$.
} 
individuals (and their spouses) participating in the survey, provided by the tax registers of Statistics Sweden. The survey variables are exclusively available for the years when the Swedish Level of Living survey was conducted, whereas the register data also are available for surrounding years. The survey and register variables have been utilised in the calculation of budget constraints. During the time period of study the individual, and not the household, was the taxable unit with respect to taxation of labor incomes. ${ }^{13}$

We restrict the sample to those who were married or cohabiting both in 1981 and 1991. This is because spousal income is a central part of the virtual income measure. In addition, we only include individuals of working age. Since no married individuals in the data were younger than 22 in 1981 our data set consists of individuals who were aged 22-54 in 1981 (and 32-64 in 1991). We exclude those who were self-employed either in 1981 or 1991 or in both years since hourly wage rates are obtained for employees only. Exclusions have also been made due to missing values for some of the variables included in the regressions and the variables needed to calculate the housing allowance. Our final sample consists of 586 males and 522 females. $^{14}$

The hourly wage rate variable, which is the dependent variable in many of the regressions, is measured by a number of survey questions, where respondents are asked to report different kinds of wage income. The wage rate variable is highly comparable between the two years. If respondents are not paid on an hourly basis, the hourly wage rate is obtained as a ratio between weekly or monthly pay and reported normal hours of work. Thus, our wage rate measure has not been obtained by dividing a taxable earnings measure with reported hours of work, which is the case in many other data sets. Hence, given that the measurement errors in the wage rate are distributed with zero mean, which is a very reasonable assumption, measurement errors do affect the efficiency, but not the consistency, of our estimates.

The taxable labor income variable, which is our second dependent variable, is taken from the tax registers. It is defined as the earnings net of costs of earning the income. These costs are mainly the tax deductible part of work related travel costs. Hence, our taxable labor income concept does not embrace the Swedish counterpart to 'itemized deductions' in the

\footnotetext{
${ }^{13}$ Joint taxation of capital income was abolished in 1986. However, wealth was taxed on a joint family basis during the whole time period of study.

${ }^{14}$ Since our estimation procedure requires individuals to fulfil the inclusion criteria both in 1981 and 1991 the sample size is a bit smaller than what is common for labor supply studies conducted on this data source. E.g. Blomquist et. al. (2001) include 864 prime aged married men from the 1981 wave of the survey and 680 married men from the 1991 wave.
} 
U.S. In essential respects, the definition of the taxable labor income concept is similar between the two years. ${ }^{15}$

Figure 3 and Figure 4 depict the 1981 and 1991 levels of log real wages and log taxable labor income respectively by income decile. Visual inspection of the first graph suggests that the overall growth in real wages was quite low between the two years. The percentage growth is, however, somewhat higher in the uppermost deciles. The tendency of slightly higher wage dispersion during the 1980's has earlier been documented by Edin and Holmlund (1995). Figure 4 shows that taxable labor income has increased quite evenly across the sample as well, even though the increase is somewhat smaller in the middle deciles. One should remember that the individuals participating in the sample were 10 years older in 1991 than in 1981.

The main lesson from Figure 3 and Figure 4 is though that the evolution of the Swedish wage and income distribution during the 1980's was very different from its U.S. counterpart. In the U.S. there was a sharp increase in income inequality during the same time period. ${ }^{16}$

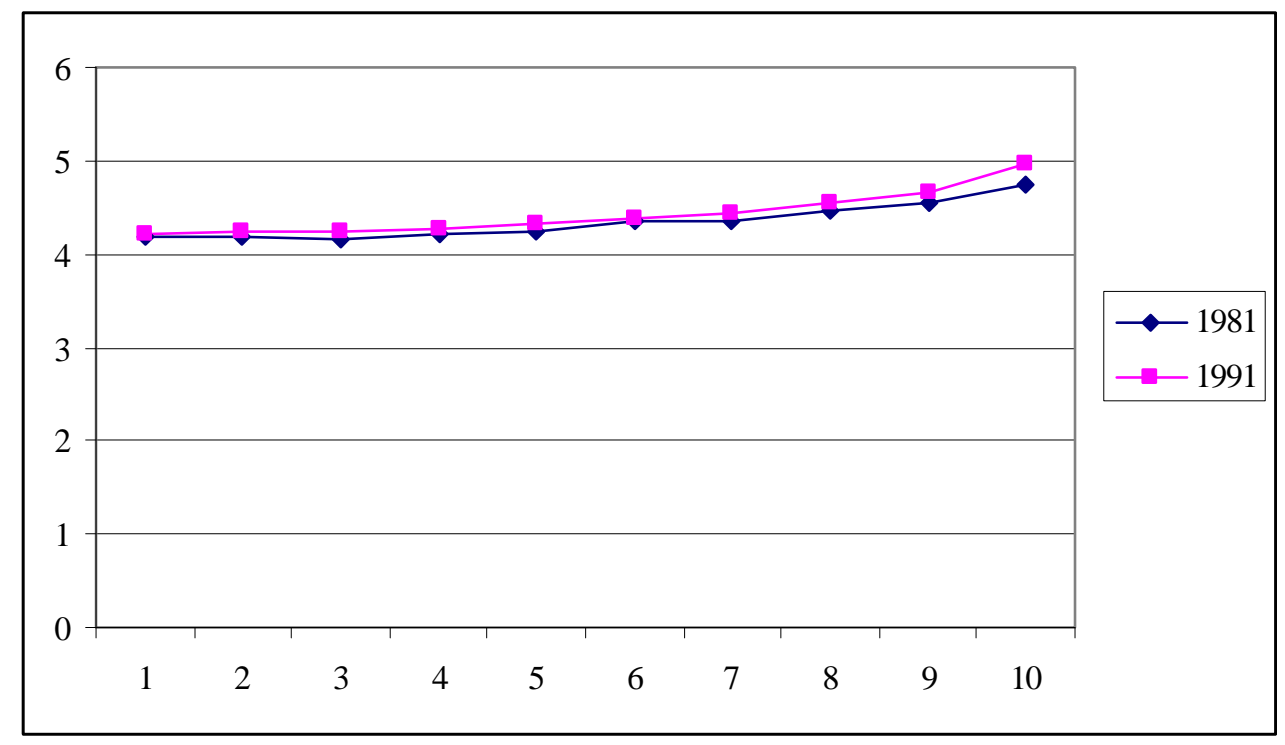

Figure 3. Average log real hourly wage rates in 1981 and 1991 by income decile based on taxable labor income in 1986. Hourly wage rates in 1981 have been inflated to the 1991 price level by the consumer price index. Men and women are pooled.

\footnotetext{
${ }^{15}$ See e.g. Slemrod (1998) and Aarbu and Thoresen (2001) for discussions of the importance to use a constant tax base between the two years. In Sweden, the wider taxable income concepts changed dramatically in 1991 as dual income taxation (i.e. separate taxation of capital and labor income) was introduced.

${ }^{16}$ See Freeman and Katz (1995) for a comparison between countries. Goolsbee (2000) has argued for that trends in income equality pose a serious methodological problem for estimating taxable income elasticities on U.S. data.
} 


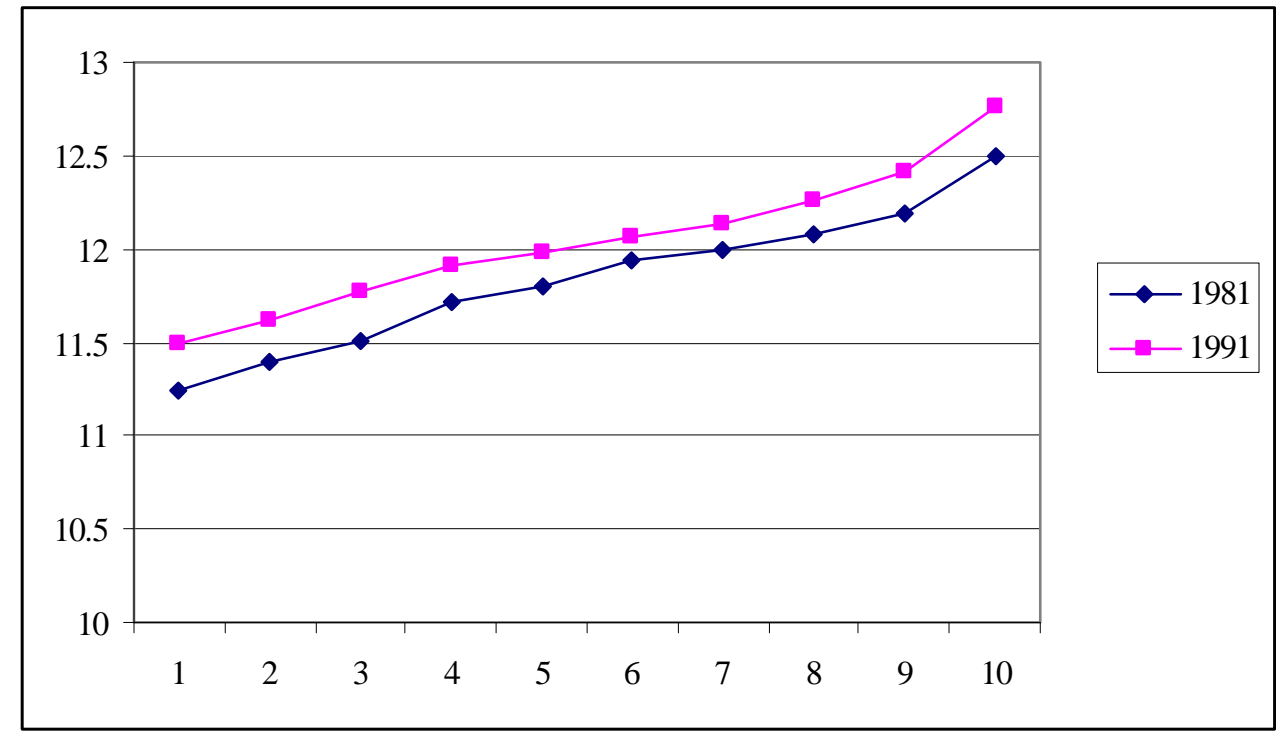

Figure 4. Average log real taxable labor income in 1981 and 1991 by income decile based on taxable labor income in 1986. Taxable labor incomes in 1981 have been inflated to the 1991 price level by the consumer price index. Men and women are pooled.

\section{Estimation results}

In this section we present the estimation results. Since we have found that the structure differs between men and women we report results for each gender separately. Throughout the 2SLS estimations, the first stage F-statistics of the excluded instruments are always high and not reported. Thus, the instruments are strongly correlated with the instrumented regressors.

Regression results for log hourly wage rates are reported in Table 1, whereas the results for log taxable labor income are described in Table 2. These tables share a common structure. The first four columns of each table display the results for married males; the last four columns display the results for married females. In the first column we have included a set of socio-demographic control variables, but no income controls. In the second column we have controlled linearly for the log of average lagged taxable labor income. The third column shows the results when instead a 10-piece spline in log average lagged taxable labor income is added to the regression. The fourth column, finally, reflects the situation when the coefficient for the virtual income term is constrained to be zero. To ease exposition, we only report the key estimates -- full results can be provided upon request. 


\subsection{Hourly wage rates}

Columns (1)-(4) of Table 1 convey an interesting message: male log hourly wage rates exhibit a sharp response to log net-of-tax rates. The elasticity estimate is 0.14 when income controls are disregarded (column 1). When income controls are included the net-of-tax rate elasticity slightly increases. When the 10-piece linear spline function is added (column 3) the elasticity estimate is 0.16 . It is worth emphasizing that all these elasticity estimates are precisely estimated. Throughout column (1)-(3) they are significant at a level of $1 \%$.

Viewed from the perspective that wage rates have been taken as given in the standard static neo-classical labor supply model our elasticity estimates must be considered as large. ${ }^{17}$ However, we do not find any evidence for that the log virtual income would affect the log hourly wage. The non-labor income elasticity estimates are always very close to zero and insignificant. In column (4), where we constrain the coefficient for the virtual income term to be zero, the net-of-tax rate elasticity estimate decreases a little bit and becomes significant at a level of $5 \%$.

Columns (5)-(8) of Table 1 show the corresponding estimates for married females. Interestingly, the wage rate elasticities are considerably higher for women than for men. In column (6)-(8) the elasticity estimates are significant at a level of 5\%. It is noteworthy that the inclusion of income controls has a greater impact on the results for women than for men. In particular, the elasticity estimate appears to be downward biased when flexible income controls are absent. Without income controls the net-of-tax rate elasticity amounts to 0.39 , but when the 10-piece spline function is added the net-of-tax rate elasticity increases to 0.5 . In similarity to males, the non-labor income elasticities are always close to zero for females. Given that the responsiveness in wage rates encompasses other dimensions of work effort than hours worked, the larger female elasticities is in line with the stylized fact that female labor supply is more responsive to tax changes than male labor supply. As for men, non-labor income elasticities are estimated to be small and not significantly different from zero.

\footnotetext{
${ }^{17}$ From a completely different point of departure Holmlund and Kolm (1995) have regressed changes in logged hourly wage rates, obtained by dividing earnings with a survey variable of number of hours worked for full time workers, on changes in a logged measure of tax progressivity and average tax rates. Their model framework, where a trade union and a firm bargain over wages and unemployment, predicts that tax progressivity should lead to wage moderation. Their regression results show that the coefficients for the tax progressivity measure, where the marginal tax rate of course is an essential element, generally are significant and with expected sign. As actually noted by Holmlund and Kolm (1995), this is also consistent with the interpretation that individuals might change their work effort in response to changes in tax progressivity.
} 
Table 1. 2SLS Regression Results for Log Hourly Wage Rates.

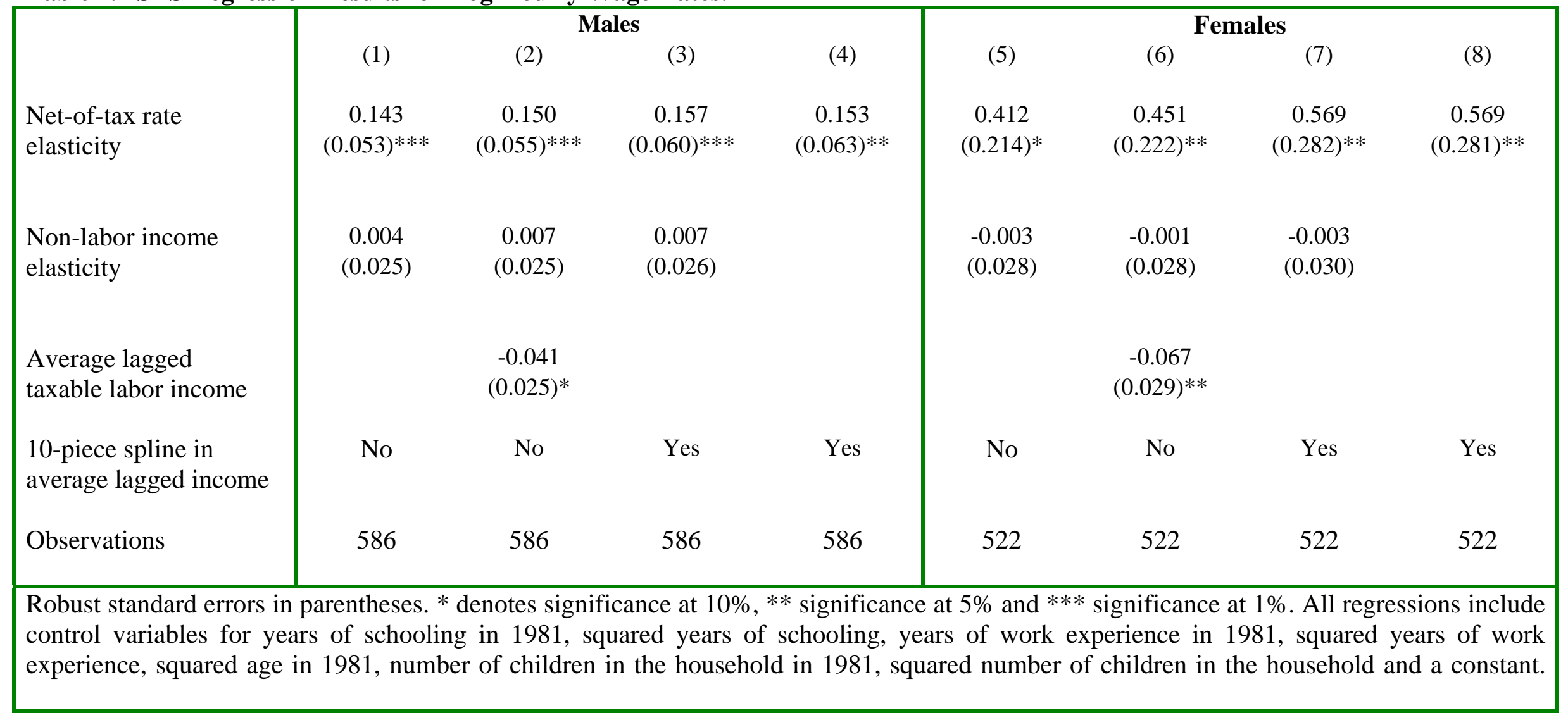


Table 2. 2SLS Regression Results for Log Taxable Labor Income.

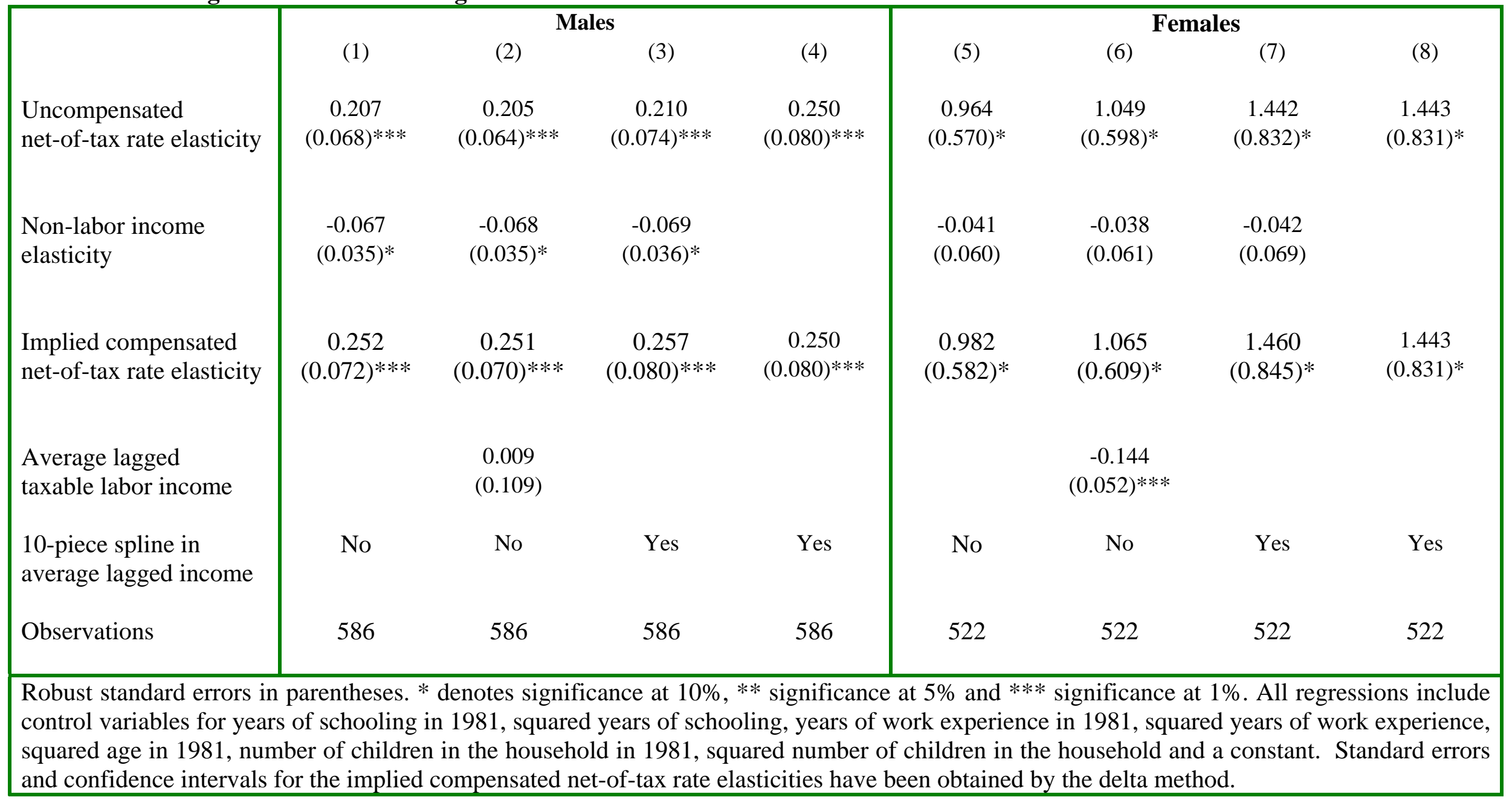




\subsection{Taxable labor income}

Table 2 reports the regression results when log taxable labor income is the dependent variable. For taxable labor income we in addition to the uncompensated elasticities also report the implied compensated elasticities. The latter have been obtained from the Slutskydecomposition described in equation (1) in section 3.1. The estimated uncompensated taxable labor income elasticity for males is always significantly different from zero at a level of 1 percent. It is noteworthy that the (uncompensated) net-of-tax rate elasticity estimates for males are insensitive to the inclusion of income controls. Throughout columns (1)-(3) the netof-tax rate elasticity estimates can be rounded to 0.21 .

However, the most remarkable feature of column (1)-(3) of Table 2 is that the non-labor income elasticites are statistically significant at a level of $10 \%$. Moreover, they take on expected sign. When income controls are added the non-labor income elasticity is estimated to be around -0.07 (column 2-3). Remember that this is the first study in the taxable income literature that specifies virtual incomes. The main bulk of the previous literature has implicitly constrained the non-labor income elasticity to be 0. Column (4) reports the uncompensated net-of-tax rate elasticity when this restriction is imposed. The uncompensated net-of-tax rate elasticity is now estimated to 0.25 , i.e. 4 percentage points higher as compared to column (3). This suggests that the net-of-tax rate coefficient potentially picks up variation that should be ascribed to the virtual income term.

Since we did not find any significant income effects when estimating hourly wage rates a plausible interpretation is that the income effect works through the labor supply choice in terms of hours worked.

The estimates for males are comparable with those previously obtained on Swedish data by Hansson (2007). She estimates a net-of-tax rate elasticity of 0.29 for males. While using a family model, where spouses consider each other's net-of-tax rates, Gelber (2008), also on Swedish data, estimates own net-of-tax rate elasticities to be 0.17 for males, which is by and large of the same magnitude as our estimates for married males.

An implication of our results is that the compensated taxable labor income elasticity is estimated to be larger than the uncompensated one. If we apply the simple formula in (1) and evaluate the term $\{[(1-\tau) z] / R\}$ at the male sample mean values of $(1-\tau), z$ and $R$ we obtain a compensated taxable labor income elasticity, $\zeta^{c}$, of a magnitude of $0.25-0.26 .{ }^{18}$

\footnotetext{
${ }^{18}$ For males we have that $\{[(1-\tau) z] / R\}=(0.4747 * 209,006) / 146,262=0.6783$. The mean values have been obtained by pooling the 1981 and 1991 male observations in the sample. Nominal values for $z$ and $R$ and have
} 
In some sense, it is good news for the previous literature that we obtain approximately the same compensated elasticities when we constrain the virtual income term to be zero. For welfare evaluation, the compensated elasticity is the relevant measure (Feldstein 1999). Still, in some applications we want to know what actually happens with the income supply and tax revenues if we alter certain tax parameters. Then the uncompensated elasticity is the relevant elasticity and this might be incorrectly estimated if the virtual income term is omitted.

For females the taxable labor income elasticity with respect to the net-of-tax rate is estimated to be considerably larger than for males. The elasticity estimates hover between 0.96 and 1.44. In similarity with Table 1 the estimates for females are less precise than corresponding estimates for males. Still, they are all significant at a level of 10 percent. Larger standard errors for females were expected for two reasons. First, since women on average are to be found in lower tax brackets the variation in the change in log net-of-tax rates is smaller for them. ${ }^{19}$ Second, the size of the female sample is smaller.

For females the non-labor income elasticity estimates are of expected sign and around -0.045. However, these estimates are far from being significantly distinct from zero. The compensated elasticities, evaluated at the female sample mean values of $(1-\tau), Z$ and $R$, are approximately 2 percentage points larger than the uncompensated ones.

Labor supply studies previously conducted on the same data set, the Swedish Level of Living Survey, have obtained hours of work elasticities with respect to the net wage rate of a magnitude of 0.08-0.1 (e.g. Blomquist and Newey 2002, Blomquist et. al. 2001) for men and 0.3-0.75 for women (Blomquist and Hansson-Brusewitz 1990, Liang 2008). It is worth noting that the earlier obtained male and female labor supply elasticities and the hourly wage rate elasticities reported in Table 1 by and large add up to the taxable labor income elasticities shown in Table 2 both for males and females.

\section{Concluding discussion}

Using Swedish panel data from 1981 and 1991, spanning a time period with large changes in the Swedish tax system, we study how hourly wage rates as well as taxable labor income react to changes in marginal tax rates and non-labor income. In particular, we would like to emphasize three contributions to the literature on the elasticity of taxable income.

been inflated to the 1991 price level by the consumer price index. For females the corresponding value is $\{[(1-\tau) z] / R\}=(0.5964 * 124,863) / 171,434=0.4344$.

${ }^{19}$ See appendix B for descriptive statistics. 
First, previous literature has almost exclusively used instruments for the change in netof-tax rates that are functions of first period income. In general this will create instruments that are invalid. To "solve" this endogeneity problem it is common practice to include some function of first period income as a regressor in the estimated function. However, we have not come across any reasonable explanation why this should solve the problem. Our data permit us to use a different strategy. We use exogenous individual characteristics as well as income from 1986, the year in the middle of the time period considered, to construct our instruments. The intuitive appeal of this way to construct instruments is that, even in the presence of substantial first-order auto-correlation in the transitory shocks, the shock in 1986 would show a very weak correlation with either the shock in 1981 or 1991.

Second, a large part of the literature on the elasticity of taxable income has neglected the effect of non-labor income. This implies that one has not been able to estimate the compensated effect of the net-of-tax rate, even though it is well known that it is the compensated effect that is central to calculations of welfare losses. We use a method to calculate "virtual" non-labor income that is common practice in the labor supply literature, but which has not previously been adopted in the taxable income literature. For men we find a significant income effect when we estimate the taxable labor income elasticity; in our preferred specification the elasticity of taxable labor income with respect to non-labor income is -0.07 . The compensated and uncompensated elasticities with respect to net-of tax rates are 0.21 and 0.25 respectively. For women the non-labor income effect is not significant. The compensated and uncompensated elasticities with respect to net-of tax rates are 1.44 and 1.46 respectively.

Third, as highlighted by Slemrod and Kopczuk (2002) and Kopczuk (2005) the elasticity of taxable income is a reduced form parameter and to some extent under government control. An implication of this is that it would be of value to know the anatomy of the behavioral response. A similar point is emphasized in the concluding section of Saez (2003). In this study, we have taken a step forward in this direction by focusing directly on how hourly wage rates respond to changes in marginal tax rates. Of course, a caveat is that we cannot discriminate between effort responses and shifts in the form of compensation from leniently taxed fringe benefits to fully taxed cash pay.

The effect of changes in non-labor income on changes in the wage rate is not significant. However, we have found a marked response in hourly wage rates to changes in the net-of-tax rate: the elasticity estimates are in the range $0.14-0.16$ for males and $0.41-0.57$ for females. These results suggest that wage responsiveness to tax changes is just as important 
as hours of work responses, or perhaps even more important. Furthermore, as explained above, the hourly wage rate elasticities obtained here are consistent with our own estimated taxable labor income elasticities and earlier estimated hours of work elasticities. 


\section{References}

Aarbu, K.O. and T.O. Thoresen (2001) 'Income responses to tax changes - evidence from the Norwegian tax reform’, National Tax Journal 54, 319-38.

Agell, J, Englund, P, and J. Södersten (1998) Incentives and redistribution in the welfare state: The Swedish tax reform, New York: St. Martin's Press; London: Macmillan Press.

Auten, G. and R. Carroll (1999) 'The effect of income taxes on household income', The Review of Economics and Statistics 81, 681-693.

Blomquist, N.S. (1979) 'Wage rates and personal characteristics', Scandinavian Journal of Economics 81(4), 505-20.

Blomquist, N. S. (1988) 'Nonlinear Taxes and Labor Supply', European Economic Review 32, 1213-1226.

Blomquist, S., Eklöf, M and W. Newey (2001) 'Tax reform evaluation using non-paramtric methods: Sweden 1980-1991’, Journal of Public Economics 79(3), 543-68.

Blomquist, S. and W. Newey (2002) 'Non-parametric estimation with non-linear budget sets' Econometrica 70(6), 24555-80.

Blomquist S. and U. Hansson-Brusewitz 'The effect of taxes on male and femal labor supply in Sweden', Journal of Human Resources 25(3), 317-57.

Carroll, R. (1998) 'Do taxpayers really respond to changes in tax rates? Evidence from the 1993 tax act’, OTA Working Paper 79.

Chetty, R. (2008) 'Is the taxable income elasticity sufficient to calculate deadweight loss? The implications of evasion and avoidance', forthcoming American Economic Journal Economic Policy.

Edin, P.A and B. Holmlund (1995) 'The Swedish wage structure: the rise and fall of solidarity wage policy?' in Differences and changes in wage structures, R.B. Freeman (Ed.) and L.F. Katz (Ed.), National Bureau of Economic Research Comparative Labor Markets Series. Chicago and London: University of Chicago Press.

Feldstein, M. (1995) 'The effect of marginal tax rates on taxable income: A panel study of the 1986 tax reform act’, Journal of Political Economy 103, 551-72.

Feldstein, M. (1999) 'Tax avoidance and the deadweight loss of the income tax', Review of Economics and Statistics 81(4), 674-80.

Freeman R.B. and L.F. Katz (1995) Differences and changes in wage structures, National Bureau of Economic Research Comparative Labor Markets Series. Chicago and London: University of Chicago Press.

Fritzell, J. and O. Lundberg (1994), Vardagens villkor: levnadsförhållanden I Sverige under tre decennier, Brombergs förlag.

Gelber, A.M. (2008) 'Taxation and family labor suuppply’, Job market paper, Harvard University.

Giertz, H.G. (2004) 'Recent literature on taxable-income elasticities' Congressional Budget Office 2004-16.

Giertz , H.G. (2007) 'The elasticity of taxable income over the 1980's and 1990's' National Tax Journal 60(4), 743-68. 
Goolsbee, A. (2000) 'It's not about the money: Why natural experiments don't work on the rich' in Does Atlas shrug? The economic consequences of taxing the rich, J. Slemrod (Ed.). Harvard, Russell Sage Foundation.

Gruber, J. and E. Saez (2002) 'The elasticity of taxable income: Evidence and implications', Journal of Public Economics 84, 1-32.

Hansson, Å. (2007) 'Taxpayers responsiveness to tax rate changes and implications for the cost of taxation', International Tax and Public Finance 14(5), 563-82.

Heim, B. T. and B. D. Meyer (2004) 'Work costs and nonconvex preferences in the estimation of labor supply models’ Journal of Public Economics 11, 2323-2338.

Holmlund, B. and M. Söderström (2007) 'Estimating income responses to tax changes: a dynamic panel data approach’ Working paper 2007:25. Department of Economics, Uppsala University.

Holmlund, B. and A.S. Kolm (1995) 'Progressive taxation, wage setting, and unemployment: theory and Swedish evidence’, Swedish Economic Policy Review 2 (1995), 423-460.

Kopczuk, W. (2005) 'Tax bases, tax rates and the elasticity of taxable income', Journal of Public Economics 89, 2093-2119.

Liang, C. (2008) 'Nonparametric estimation of female labor supply and the 2007 Swedish earned income tax credit reform', in C. Liang Essays in Political Economics and Public Finance, Economic Studies 112, Department of Economics, Uppsala University.

Lindsey, L. (1987) 'Individual taxpayer response to tax cuts: 1982-1984: With implications fo the revenue maximizing tax rates', Journal of Public Economics 33(2), 173-206.

Ljunge, M. and K. Ragan (2006) 'Labor supply and the tax reform of the century?', University of Chicago, mimeo.

Moffitt, R.A. and M.O. Wilhelm (2000) 'Taxation and the labor supply decisions of the affluent', in Does Atlas shrug? The economic consequences of taxing the rich, J. Slemrod (Ed.). Harvard, Russell Sage Foundation.

Saez, E. (2003) 'The effect of marginal tax rates on income: a panel study of 'bracket creep', Journal of Public Economics 87(5-6), 1231-58.

Saez, E. (2004) 'Reported income and marginal tax rates, 1960-2000: Evidence and policy implications’, NBER working paper 10273.

SCB (2005) 'Sysselsättning och arbetslöshet 1976-2004'. Statististiska centralbyrån. Avdelningen för arbetsmarknads- och utbildningsstatistik 2005-11-21.

Selén, J. (2004) 'Taxable income responses to tax changes: Panel analyses of Swedish reforms', Mimeo, Trade Union Institute for Economic Research.

Sillamaa and Veall (2001) 'The effect of marginal tax rates on taxable income: A panel study of the 1988 tax flattening in Canada', Journal of Public Economics 80(3), 341-56.

Slemrod, J. (1998) 'Methodological issues in measuring and interpreting taxable income elasticities', National Tax Journal 51, 773-88.

Slemrod, J. and W. Kopczuk (2002), 'The optimal elasticity of taxable income', Journal of Public Economics, 84(1), 91-112.

Wooldridge, J.M. (2002) Econometric analysis of cross section and panel data, Cambridge and London: MIT Press. 


\section{Appendix A. The Swedish tax and transfer system in 1981 and 1991}

\section{A.1 The statutory income tax schedule}

A global income tax system was in place in Sweden in 1981, i.e. earned income and unearned income (capital income) were taxed according to the same income tax schedule, a schedule that is illustrated in Table A.1. The statutory 'federal' tax schedule was in general highly progressive and contained 22 brackets. However, a special tax reduction caused the marginal tax rate to actually decrease over some intervals. There were also two caps for the marginal tax rate. Below SEK192,000 SEK the marginal tax rate ('federal' marginal tax rate + local tax rate) was not allowed to exceed $0.8 .^{20}$ And above 192,000 the maximum limit was 0.85 .

Table A.1. Statutory Income Tax Schedule in 1981

\begin{tabular}{|c|c|c|c|}
\hline Assessed income & Marginal tax rate & Assessed income & Marginal tax rate \\
\hline $0-6,400$ & 0 & $64,000-70,400$ & 0.5455 \\
\hline $6,400-25,600$ & 0.3155 & $70,400-76,600$ & 0.5855 \\
\hline $25,600-32,000$ & 0.3355 & $76,600-76,800$ & 0.5555 \\
\hline $32,000-38,400$ & 0.3455 & $76,800-83,200$ & 0.5855 \\
\hline $38,400-40,000$ & 0.3755 & $83,200-89,600$ & 0.6255 \\
\hline $40,000-44,800$ & 0.2755 & $89,600-96,000$ & 0.6755 \\
\hline $44,800-44,900$ & 0.3055 & $96,000-102,400$ & 0.7355 \\
\hline $44,900-51,200$ & 0.4055 & $102,400-108,800$ & 0.7455 \\
\hline $51,200-57,600$ & 0.4355 & $108,800-128,000$ & 0.7755 \\
\hline $57,600-60,000$ & 0.4955 & $128,000-192,000$ & 0.8 \\
\hline $60,000-64,000$ & 0.5155 & above 192,000 & 0.85 \\
\hline
\end{tabular}

Marginal tax rates are reported for an individual with an average

local tax rate $(=0.2955)$

The global income tax system was abandoned in 1991. In the new dual income tax system capital income was taxed at a proportional rate of 0.3 , whereas earned income was still taxed according to a progressive income tax schedule. If a deficit in capital income would emerge, the taxpayer could deduct a fraction of the deficit from the tax on earned income. ${ }^{21}$ The number of brackets was seven in 1991 - a considerably lower amount of segments than in

\footnotetext{
${ }^{20}$ Throughout this appendix we use the nominal values for both years. The 1981 income values can be deflated to the 1991 price level by a factor $272.2 / 112.1$ by the consumer price index.

${ }^{21}$ The tax reduction amounted to 30 percent of the deficit given that the deficit was lower than 100,000 SEK. Above that limit only 21 percent of the deficit could be deducted. The tax reduction was, however, not allowed to exceed the tax payment on earned income.
} 
1981. As can be viewed in Table A.2, in the highest income tax bracket the marginal tax rate was 0.5112 for an individual with an average local tax rate. The regressive elements of the tax schedule were due to the phase-out region of the standard deduction. For assessed earnings below SEK 63,892 and above SEK 184,803 the standard deduction amounted to SEK $10,304 .^{22}$ In the interval 63,892 SEK to 101,888 SEK the standard deduction increased at a rate of 0.25 . However, between 101,888 and 184,803 it decreased at a rate of 0.1 .

\section{Table A.2. Statutory Income Tax Schedule in 1991}

\begin{tabular}{|c|c|}
\hline Assessed earnings & Marginal tax rate \\
\hline $0-14,304$ & 0 \\
\hline $14,304-63,892$ & 0.3115 \\
\hline $63,892-97,058$ & 0.2336 \\
\hline $97,058-101,888$ & 0.3115 \\
\hline $101,888-184,349$ & 0.3427 \\
\hline $184,349-184,803$ & 0.5671 \\
\hline above 184,803 & 0.5155 \\
\hline
\end{tabular}

Marginal tax rates are reported for an individual with an average local tax rate $(=0.3155)$

\section{A.2 Housing allowance}

An important feature of the system for housing allowances in Sweden was that the allowance was dependent on household income, which created an additional marginal effect for the individual. In both 1981 and 1991, the allowance entailed two components. First, the maximal amount of housing allowance was calculated as a function of the qualifying housing costs and family composition. ${ }^{23}$ Second, the maximal allowance was reduced according to a set of reduction rates that were determined by qualifying income and household composition. The reduction rates and marginal tax rates for given income levels were then merged to a common vector when calculating the budget constraints.

The annual maximal housing allowance in 1981 can be written as

$\mathrm{MH}_{81}=$ number of children $* 1,860 \mathrm{SEK}+($ qualifying housing cost SEK $-500 \mathrm{SEK}) * 0.8$

\footnotetext{
${ }^{22}$ There was also a standard deduction, which was 4,000 SEK for taxpayers earning more than 40,000 SEK.

${ }^{23}$ In 1991 special rules applied to individuals aged below 29. Since our sample consists of individuals between 19 and 54 years of age in 1981, these rules do not affect any observations in our study. Therefore, we do not report them here.
} 
The qualifying housing costs were not allowed to exceed certain levels, where the maximum levels were determined by household composition. ${ }^{24}$ The housing cost limits for 1981 are reported in Table A.3 below.

Table A.3. Limits for Qualifying Housing Costs in 1981

\begin{tabular}{|c|c|}
\hline Number of children & Housing cost limit \\
\hline 0 & $750(S), 850(M)$ \\
\hline $1-2$ & 1,250 \\
\hline $3-4$ & 1,500 \\
\hline more than 4 & 1,800 \\
\hline
\end{tabular}

(S) denotes singles and (M) married.

In the 1991 system the corresponding maximal housing allowance, for households with children, can be written

$\mathrm{MH}_{91}=1,000 \mathrm{SEK}+$ qualifying housing cost SEK

Furthermore, the qualifying housing cost is determined by the number of children. Table A.4 reports the lower, middle and upper limits for qualifying housing costs in 1991. The transfer covers 75 percent of the costs between the lower and middle limit and 50 percent of the cost between the middle and upper limit. For two-person or single households without children the maximal transfer was equal to 30 percent of the costs between 1,600 SEK and 3,500 SEK.

\footnotetext{
${ }^{24}$ For rented (and co-opereative) apartments the housing authorities use the reported rent as a basis of housing cost. For owner-occupied homes interest payments, tax on real estate and regional location, size of housing and type of housing are used when computing the housing costs. For 1981 we use a survey-based total measure of housing costs, whereas we for 1991 instead are able to utilise survey variables for housing type and size and register variables on interest deductions and real estate tax in order to calculate housing costs according to the template that the housing authorities employ.
} 
Table A.4. Limits for Qualifying Housing Costs in 1991

\begin{tabular}{|c|c|c|c|}
\hline Number of children & Lower & Middle & Upper \\
\hline 1 & 1,800 & 2,400 & 3,500 \\
\hline 2 & 1,500 & 2,800 & 4,000 \\
\hline more than 2 & 1,200 & 3,200 & 4,500 \\
\hline
\end{tabular}

In both 1981 and 1991 the qualifying income, which determines the reduction rate, is based on total income of the household and wealth exceeding a certain amount. ${ }^{25}$ If the present year household income was in the neighbourhood of the household income two years earlier, the allowance was based on the latter. In this interval, there was no additional marginal effect from the housing allowance system. But for larger changes, the amount of the transfer was dependent on the income acquisition in the present year. The maximal allowance was reduced according to Table A.5 for 1981 and Table A.6 for 1991. At some point the entire allowance was taxed away. After that point the marginal effect from housing allowances was zero.

Table A.5. Rate of Reductions in Housing Allowance for Households in 1981

\begin{tabular}{|c|c|}
\hline Aggregated total income 1981 & Rate of reduction \\
\hline If $Y_{79}<a 1$ & 0 \\
\hline $0-(a 1+20,000)$ & 0.15 \\
\hline$(a 1+20,000)-(a 2+20,000)$ & 0.24 \\
\hline$(a 2+20,000)-$ & 0 \\
\hline If $a 1<Y_{79}<a 2$ & 0.15 \\
\hline $0-(a 1-5,000)$ & 0 \\
\hline$(a 1-5,000)-\left(Y_{79}-5,000\right)$ & 0.15 \\
\hline$\left(Y_{79}-5,000\right)-\left(Y_{79}+20,000\right)$ & 0.24 \\
\hline$\left(Y_{79}+20,000\right)-(a 2+20,000)$ & \\
\hline$(a 2+20,000)-$ & 0 \\
\hline If $Y_{79}>a 2$ & \\
\hline $0-(a 1-5,000)$ & \\
\hline
\end{tabular}

\footnotetext{
${ }^{25}$ In 1981, 20 percent of wealth exceeding 75,000 SEK was added to the qualifying income. In 1991, 20 percent of wealth exceeding 180,000 SEK for spouses and 90,000 for singles was included. Net loss of source of income exceeding 4,000 SEK was also taken into account in the 1981 qualifying income measure.
} 


\begin{tabular}{|c|c|}
\hline$(a 1-5,000)-(a 2-5,000)$ & 0.15 \\
\hline$(a 2-5,000)-\left(Y_{79}-5,000\right)$ & 0.24 \\
\hline$\left(Y_{79}-5,000\right)-\left(Y_{79}+20,000\right)$ & 0 \\
\hline$\left(Y_{79}+20,000\right)-$ & 0.24 \\
\hline
\end{tabular}

$Y_{79}$ is aggregated total income in 1979. a1 equals 29,000 SEK for single and two-person households without children, 38,000 SEK for spouses with children and 30,000 for singles with at least one child. $a 2$ is equal to 59,000 for all.

\section{Table A.6. Rate of Reductions in Housing Allowance for Households in 1991}

\begin{tabular}{|c|c|}
\hline Aggregated total income 1991 & Rate of reduction \\
\hline \multicolumn{2}{|l|}{ If $Y_{89}<a$} \\
\hline $0-(a+50,000)$ & 0 \\
\hline$(a+50,000)-$ & $B$ \\
\hline \multicolumn{2}{|l|}{ If $Y_{89}>a$} \\
\hline $0-(a-15,000)$ & 0 \\
\hline$(a-15,000)-\left(Y_{89}-15,000\right)$ & $B$ \\
\hline$\left(Y_{89}-15,000\right)-\left(Y_{89}+50,000\right)$ & 0 \\
\hline$\left(Y_{89}+50,000\right)-$ & $B$ \\
\hline
\end{tabular}

$Y_{89}$ is aggregated total income in 1989. $a$ is 81,000 SEK for households with children and 66,000 SEK for households without children. $\mathrm{b}$ is 0.2 for households with children and 0.1 for households without children.

\section{A.3 Taxation of housing}

In 1981, an implicit income from owner-occupied housing was taxed together with other sources of income according to the income tax schedule in figure A.1. ${ }^{26}$ In 1991, owner occupied homes were separately taxed at a rate of 0.012 of the assessed value of the house. Both in 1981 and 1991, the assessed value was an undervaluation of the market value. When computing the imputed income from owner-occupied housing, which equals the market value multiplied with the nominal interest rate, we have therefore corrected for this by using socalled purchase-price coefficients. It has been possible to derive the assessed value from register data for both years.

\footnotetext{
${ }^{26}$ The implicit income from owner-occupied housing was determined by the ratable value of the house in a progressive manner in 1981.
} 


\section{A.4 Child allowance}

Households with children received a fixed amount, 3,000 SEK, per year and child in 1981. The 1991 child allowance system implied a basic transfer of 9,000 SEK per year and child. Moreover, for three or more children the household was provided additional transfers. ${ }^{27}$

${ }^{27}$ For 3 children the additonal transfer was 4,500 SEK, for 4 children 13,500 SEK, for 5 children 18,000 SEK, for 6 children 40,500 SEK and 7 children 54,000 SEK. 


\section{Appendix B. Descriptive statistics.}

\begin{tabular}{|c|c|c|}
\hline & Men & Women \\
\hline \multirow[t]{2}{*}{ Change in log hourly wage rate } & 0.105 & 0.068 \\
\hline & $(0.249)$ & $(0.269)$ \\
\hline \multirow[t]{2}{*}{ Change in log taxable labor income } & 0.160 & 0.254 \\
\hline & $(0.287)$ & $(0.475)$ \\
\hline \multirow[t]{2}{*}{ Change in net-of-tax rate } & 0.392 & 0.213 \\
\hline & $(0.392)$ & $(0.248)$ \\
\hline \multirow[t]{2}{*}{ Change in net-of-tax rate - instrument } & 0.366 & 0.181 \\
\hline & $(0.315)$ & $(0.194)$ \\
\hline \multirow[t]{2}{*}{ Change in virtual income } & 0.823 & 0.844 \\
\hline & $(0.483)$ & $(0.513)$ \\
\hline \multirow[t]{2}{*}{ Change in virtual income - instrument } & 0.823 & 0.862 \\
\hline & $(0.483)$ & $(0.495)$ \\
\hline \multirow[t]{2}{*}{ Log average lagged taxable labor income } & 10.917 & 10.234 \\
\hline & $(0.506)$ & $(0.664)$ \\
\hline \multirow[t]{2}{*}{ Years of schooling in 1981} & 11.346 & 10.705 \\
\hline & $(3.746)$ & $(2.970)$ \\
\hline \multirow[t]{2}{*}{ Squared years of schooling in 1981} & 142.749 & 123.402 \\
\hline & $(97.394)$ & $(68.859)$ \\
\hline \multirow[t]{2}{*}{ Years of work experience in 1981} & 18.710 & 18.621 \\
\hline & $(9.187)$ & $(9.387)$ \\
\hline \multirow[t]{2}{*}{ Squared years of work experience in 1981} & 434.314 & 434.671 \\
\hline & $(367.4389)$ & $(378.493)$ \\
\hline \multirow[t]{2}{*}{ Squared age in 1981} & 1507.783 & 1460.188 \\
\hline & $(598.714)$ & $(626.900)$ \\
\hline \multirow[t]{2}{*}{ Number of children in 1981} & 1.510 & 1.406 \\
\hline & $(1.025)$ & $(0.983)$ \\
\hline \multirow[t]{2}{*}{ Squared number of children in 1981} & 3.329 & 2.943 \\
\hline & $(3.429)$ & $(3.528)$ \\
\hline Number of observations & 586 & 522 \\
\hline
\end{tabular}


WORKING PAPERS*

Editor: Nils Gottfries

2007:18 Meredith Beechey and Pär Österholm, The Rise and Fall of U.S. Inflation Persistence. 23pp.

2007:19 Henry Ohlsson and Donald Storrie, Long term effects of public policy for displaced workers in Sweden - shipyard workers in the West and miners in the North. 26pp.

2007:20 Niklas Bengtsson, How responsive is body weight to transitory income changes? Evidence from rural Tanzania. 38pp.

2007:21 Karin Edmark, Strategic Competition in Swedish Local Spending on Childcare, Schooling and Care for the Elderly. 38pp.

2007:22 Fredrik Johansson, How to Adjust for Nonignorable Nonresponse: Calibration, Heckit or FIML? 25pp.

2007:23 Henry Ohlsson, The legacy of the Swedish gift and inheritance tax, 18842004. 25pp.

2007:24 Ranjula Bali Swain and Fan Yang Wallentin, DOES MICROFINANCE EMPOWER WOMEN? Evidence from Self Help Groups in India. 26pp.

2007:25 Bertil Holmlund and Martin Söderström, Estimating Income Responses to Tax Changes: A Dynamic Panel Data Approach. 34pp.

2007:26 N. Anders Klevmarken, Simulating the future of the Swedish baby-boom generations. 60pp.

2007:27 Olof Åslund and Oskar Nordström Skans, How to Measure Segregation Conditional on the Distribution of Covariates. 17pp.

2007:28 Che-Yuan Liang, Is There an Incumbency Advantage or a Cost of Ruling in Proportional Election Systems? 20pp.

2007:29 Stefan Eriksson and Jonas Lagerström, Detecting discrimination in the hiring process: Evidence from an Internet-based search channel. 31pp.

2007:30 Helge Berger and Pär Österholm, Does Money Growth Granger-Cause Inflation in the Euro Area? Evidence from Out-of-Sample Forecasts Using Bayesian VARs. 32pp.

2007:31 Ranjula Bali Swain and Maria Floro, Effect of Microfinance on Vulnerability, Poverty and Risk in Low Income Households. 35pp.

\footnotetext{
* A list of papers in this series from earlier years will be sent on request by the department.
} 
2008:1 Mikael Carlsson, Johan Lyhagen and Pär Österholm, Testing for Purchasing Power Parity in Cointegrated Panels. 20pp.

2008:2 Che-Yuan Liang, Collective Lobbying in Politics: Theory and Empirical Evidence from Sweden. 37pp.

2008:3 Spencer Dale, Athanasios Orphanides and Pär Österholm, Imperfect Central Bank Communication: Information versus Distraction. 33pp.

2008:4 Matz Dahlberg and Eva Mörk, Is there an election cycle in public employment? Separating time effects from election year effects. 29pp.

2008:5 Ranjula Bali Swain and Adel Varghese, Does Self Help Group Participation Lead to Asset Creation. 25pp.

2008:6 Niklas Bengtsson, Do Protestant Aid Organizations Aid Protestants Only? $28 \mathrm{pp}$.

2008:7 Mikael Elinder, Henrik Jordahl and Panu Poutvaara, Selfish and Prospective Theory and Evidence of Pocketbook Voting. 31pp.

2008:8 Erik Glans, The effect of changes in the replacement rate on partial retirement in Sweden. 30pp.

2008:9 Erik Glans, Retirement patterns during the Swedish pension reform. 44pp.

2008:10 Stefan Eriksson and Jonas Lageström, The Labor Market Consequences of Gender Differences in Job Search. 16pp.

2008:11 Ranjula Bali Swain and Fan Yang Wallentin, Economic or Non-Economic Factors - What Empowers Women?. 34pp.

2008:12 Matz Dahlberg, Heléne Lundqvist and Eva Mörk, Intergovernmental Grants and Bureaucratic Power. 34pp.

2008:13 Matz Dahlberg, Kajsa Johansson and Eva Mörk, On mandatory activation of welfare receivers. $39 \mathrm{pp}$.

2008:14 Magnus Gustavsson, A Longitudinal Analysis of Within-Education-Group Earnings Inequality. 26pp.

2008:15 Henrique S. Basso, Delegation, Time Inconsistency and Sustainable Equilibrium. 24pp.

2008:16 Sören Blomquist and Håkan Selin, Hourly Wage Rate and Taxable Labor Income Responsiveness to Changes in Marginal Tax Rates. $31 \mathrm{pp}$.

See also working papers published by the Office of Labour Market Policy Evaluation http://www.ifau.se/ 